\title{
Automated methods for identification of bacteria from clinical specimens
}

\author{
SHOSHANA BASCOMB AND RC SPENCER* \\ From the Department of Bacteriology, Wright-Fleming Institute, St Mary's Hospital Medical School, \\ London W2 IPG, UK
}

SUMMARY Automated methods for measuring enzyme activities of bacterial suspensions in saline are described. The methods were applied to bacteria cultured from urine specimens, and specific enzyme profiles characteristic for Escherichia coli, Klebsiella sp, Proteus sp, and Pseudomonas sp were established. Identification of 294 freshly isolated strains by automated and conventional methods were compared. Results from automated identification based on eight enzyme tests and assay of protein content, all performed on a bacterial suspension made from one colony in $1 \mathrm{ml}$ of saline, agreed $100 \%$ with those obtained by conventional methods. Identification was achieved in 6 hours.

Identification of bacteria from clinical specimens involves three steps: (1) isolation of single colonies of the organism; (2) characterisation of the organism by morphological, biochemical, and serological tests; and (3) assignation of the unknown organism to a defined genus and species. The process of identification may be lengthy, depending on the kind of tests used. Specific enzyme tests such as catalase take minutes to complete, but biochemical tests, even rapid ones used in clinical bacteriology, usually require overnight incubation; and some, like the Voges-Proskauer reaction, may take two to five days. Kersters and De Ley (1967) discussed the shortcomings of tests commonly used in the identification of bacteria. They advocated the use of tests performed with resting cells which would permit detection of a single enzyme within a few hours by a procedure simple enough to apply to a large number of enzymes. Similarly, Buissière et al. (1967) detected specific enzymes by means of single substrate media inoculated with thick suspensions of organisms. Kilian and Bülow (1976) used nitrophenol substrates for the detection of five different enzymes, while Humble et al. (1977) examined the feasibility of the commercially available API ZYM system (API Laboratory Products Ltd) for characterisation of a variety of bacteria. The time required for completion of individual tests in these systems varies

* Present address: Department of Microbiology, Barnsley District General Hospital, Barnsley, S75 2EP

Received for publication 22 August 1979 from a few seconds to overnight incubation, and all steps are performed manually.

The use of continuous-flow methods in bacteriology started in the field of microbiological assay, and the earlier work was reviewed by Gerke and Ferrari (1968). Detection of bacteria by the use of the luciferase assay was described by Picciolo et al. (1976) and Johnston et al. (1976). Methods for measuring enzyme activities of bacteria were developed by Dealy and Umbreit (1965), Leclerc (1967), Bettelheim et al. (1970), Wade et al. (1971), and Trinel and Leclerc (1972). Bascomb and Grantham $(1973,1975)$ developed a general method for the assay of ammonia-releasing enzymes which provided 'specific enzyme profiles' (SEP) for bacteria. They showed the value of such a method for the differentiation of bacteria of the tribe Proteae. Bascomb (1976) described the use of automated methods for assay of dehydrogenases and nitrophenol-releasing enzymes for rapid identification of bacteria from cultured urine specimens.

This paper describes rapid automated methods for detection of a number of enzyme systems in bacterial suspensions and the application of such methods to the identification of bacteria from urine specimens. The results are compared with those of conventional tests.

\section{Material and methods}

GROWTH AND PREPARATION OF BACTERIAL SUSPENSIONS

Two hundred and ninety-four strains were tested. They were isolated from routine urine specimens 
cultured overnight at $37^{\circ} \mathrm{C}$ on MacConkey agar plates (without added sodium chloride). Only plates that showed a homogenous colony appearance were used. Bacterial suspensions were prepared in the routine diagnostic laboratory by the addition of 1-10 colonies to sterile physiological saline $(1-5 \mathrm{ml})$. The suspension was then passed on to the automated laboratory, thus ensuring that the identification was carried out by persons who had no prior knowledge of colonial appearance. For identification by conventional methods, $0.1 \mathrm{ml}$ of the original suspension was added to $5 \mathrm{ml}$ nutrient broth which was then incubated at $37^{\circ} \mathrm{C}$ for 2 hours on a Matburn rotary mixer.

This suspension was used for inoculation of a chosen set of conventional test media, a MacConkey agar purity plate, and a nutrient agar slope to be kept for further testing. The remainder of the saline suspension was tested directly by the automated system. No further attempt to standardise the bacterial suspensions was made at this stage. However, as the protein content of each suspension was determined, it was possible to calculate specific enzyme activities and thus compare enzymatic activities of the different suspensions.

DISRUPTION OF PERMEABILITY BARRIER

Cetrimide and lysozyme were included in the buffer solutions and mixed with the saline organism suspensions for $2 \frac{1}{2}$ minutes at room temperature before the addition of substrate. This halved the absorbance at $340 \mathrm{~nm}$ of all Gram-negative bacteria tested and enabled detection of cytoplasmic enzymes.

\section{EQUIPMENT}

Three parallel channels were used for continuousflow analysis in a hybrid system consisting of two samplers (Hook \& Tucker model A40 II and Newton Instruments Automatic Sampler), two proportioning pumps (Technicon Instruments, Models I and II for 14 and 26 tubes respectively), two oil baths (Technicon Instruments) each containing $2 \times 40 \mathrm{ft}$ coils and adjustable temperature control from room temperature to $100^{\circ} \mathrm{C}$, two dialyzers (Technicon AI with two sets of dialyzer plates and Gradko 6 inch block dialyzer), and three Vitation UPS photometers with 10 and $20 \mathrm{~mm}$ flow-through cuvettes connected to three Vitatron UR 401 recorders.

Manifolds were standardised as far as possible to increase the flexibility of the system.

NITROPHENOL-RELEASING ENZYMES

The manifold (Fig. 1) is a modification of that described by Tappel and Beck (1968) for the assay of phosphatases. The basic differences were the use of

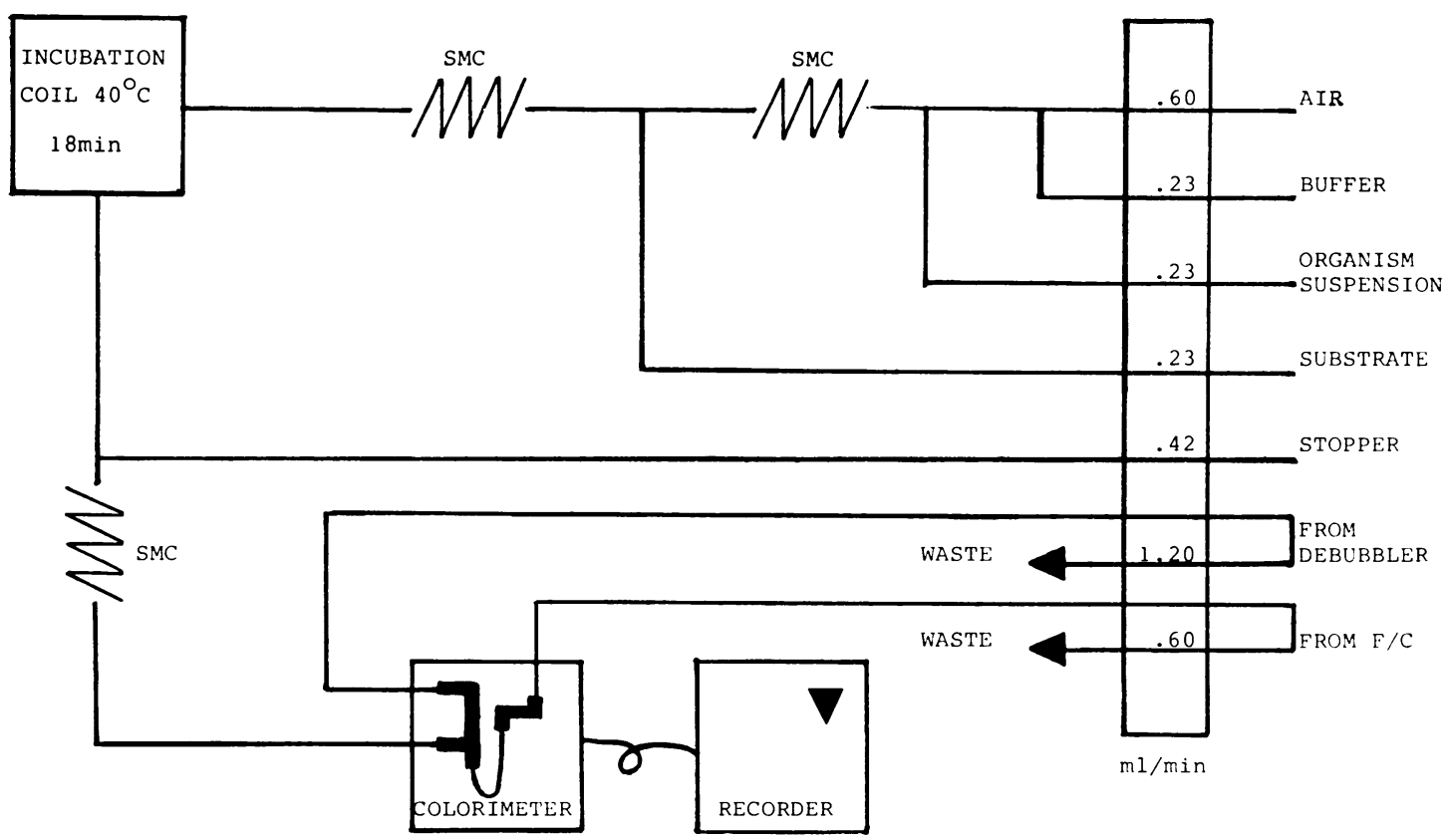

Fig. 1 Manifold for assay of nitrophenol-releasing enzymes: SMC-single mixing coil; stopper-alkaline solution containing $1.9 \mathrm{~mol} / \mathrm{l}$ ammonium hydroxide, $0.68 \mathrm{~mol} / \mathrm{l}$ sodium hydroxide and Triton-X-100 $0.3 \mathrm{~g} / \mathrm{l}$. List of buffers and substrates in Table 1. A $20 \mathrm{~mm}$ flow-cell, absorbance measured at $405 \mathrm{~nm}$. Total assay time $25 \mathrm{minutes}$. 
tubes of smaller delivery volume and increase of the proportion of enzyme to one-third of the final mixture by increasing the concentration and decreasing the volume of all other reagents. These changes permitted the testing of small amounts of enzymes.

A stream of organism suspension was mixed with an air-segmented buffer stream in the first single mixing coil (SMC). It was then mixed with the substrate stream in the second SMC and incubated for 18 minutes in one glass coil of the oil bath. The reaction was stopped by the addition of a strong alkaline solution which also acted as a colour developer for the released p-nitrophenol molecule. The stream was debubbled and passed through a 20 $\mathrm{mm}$ flow-cell in a photometer and the absorbance at $405 \mathrm{~nm}$ recorded. Because of the relatively long distances travelled by the small volumes of liquid, it was found necessary to provide pump tubes for the waste lines from both the flow-cell and the debubbler to achieve a regular bubble pattern. $p$-Nitrophenol solutions were used as standards. The enzyme systems tested with this manifold are detailed in Table 1.

\section{AMMONIA-RELEASING ENZYMES}

(LEUCINE AMMONIA-LYASE AND UREASE)

The method is based on that of Bascomb and Grantham (1975) but with different tube sizes. The manifold is shown in Figure 2. Ammonia released from the substrates was assayed firstly by adding the Nessler reagent directly to the organism/substrate stream or, secondly, by allowing the released ammonia to diffuse in a dialyzer into a $0.005 \mathrm{M} \mathrm{HCl}$ recipient stream and adding the Nessler reagent to

Table 1 Enzyme systems tested with nitrophenol derivatives

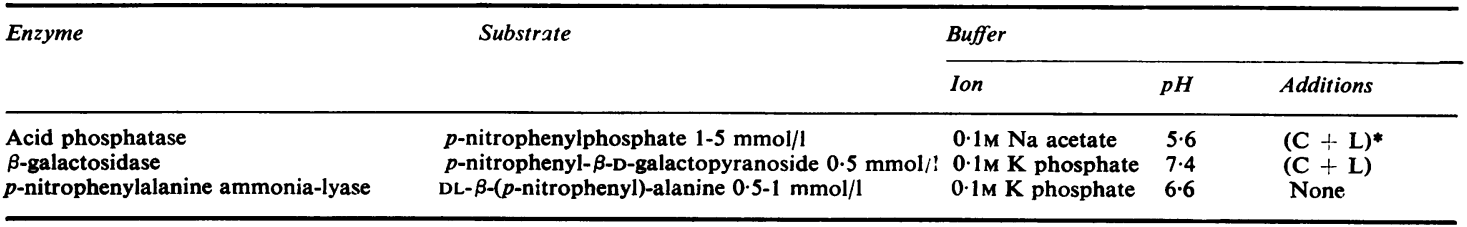

*Cetrimide and lysozyme each at a final concentration of $200 \mu \mathrm{g} / \mathrm{ml}$.

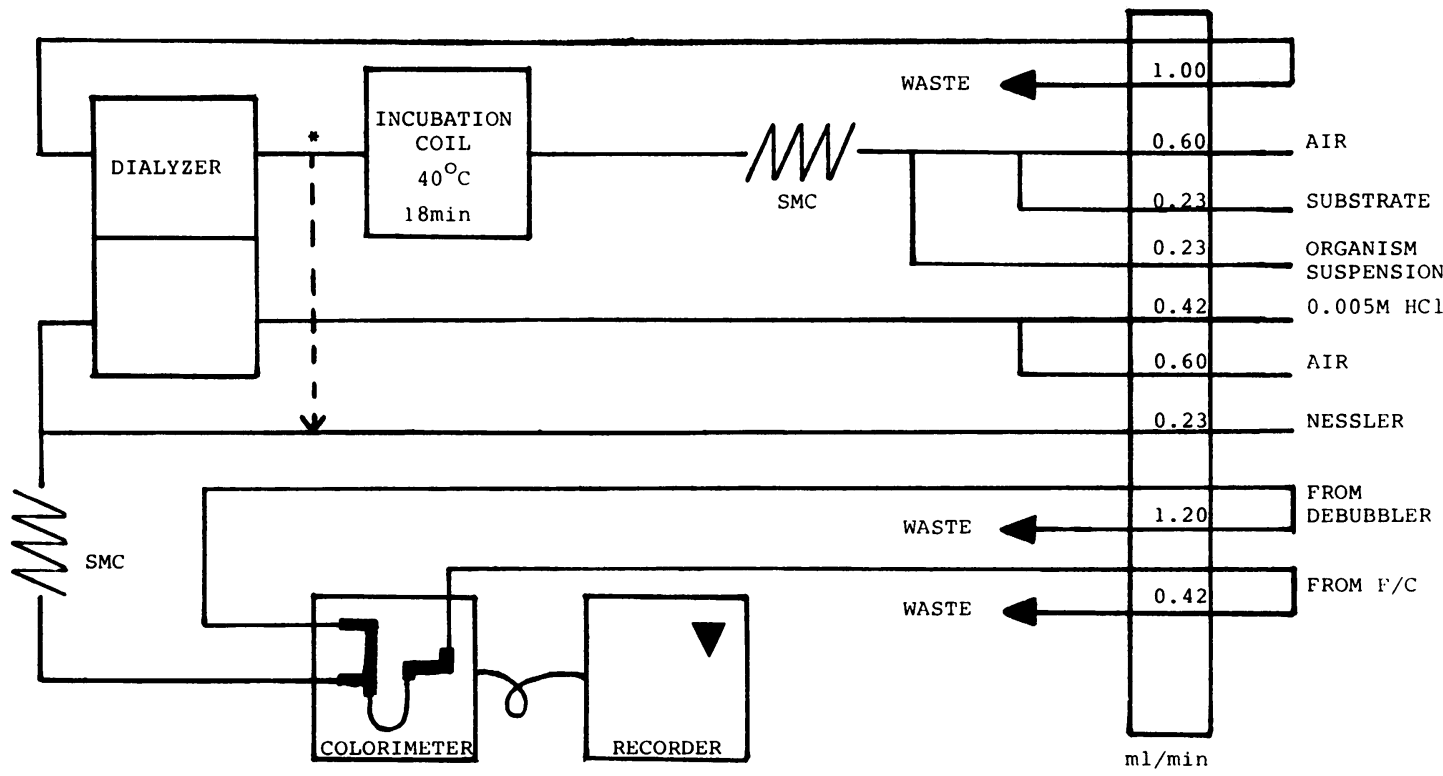

Fig. 2 Manifold for assay of ammonia-releasing enzymes. *Direction of flow without dialysis. Substrates: 5 mmol/l

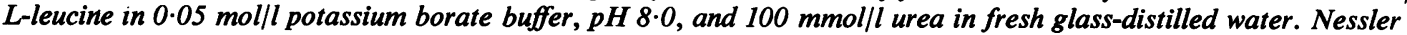
reagent prepared as described (Bascomb and Grantham, 1975) and diluted 1:10 in fresh glass-distilled water each day. A $20 \mathrm{~mm}$ flow-cell, absorbance measured at $420 \mathrm{~nm}$. Total assay time 30 minutes. 
this. The first method was more sensitive, and each bacterial suspension showed a definite peak (due to the extinction of the bacterial suspension and the colour of the ammonia-Nessler complex), making sample identification easier. However, since the trace obtained sometimes showed troublesome base-line drift and the standards were not always reproducible, the second system was eventually adopted. The inclusion of Tris maleate or phosphate buffer in the urease assay caused a noisy base-line, and the enzyme was therefore tested in the presence of distilled water only ( $\mathrm{pH}$ approximately $4 \cdot 7-5 \cdot 0$ ). $\mathrm{NH}_{4} \mathrm{Cl}$ solutions were used as standards in both assays.

\section{DIACETYL-PRODUCING SYSTEM}

(VOGES-PROSKAUER REACTION)

The V-P reaction for the presence of acetoin/ diacetyl was assayed with the manifold shown in Fig. 3, a modification of that described by Kamoun et al. (1972). Some precipitation occurred on the addition of 1-naphthol, resulting in a noisy base-line. The intensity of the colour and the base-line noise depended on the quality of 1-naphthol; BDH analar grade was found to be more satisfactory than pre- weighed $200 \mathrm{mg}$ vials of Sigma. Diacetyl solutions were used as standards.

\section{GLUTAMATE DECARBOXYLASE}

The manifold (Fig. 4) was based on those described by Leclerc (1967), Moran and Witter (1976), and Technicon Methodology AAII-08. Sodium carbonate (Technicon) standard solutions were used.

\section{CYTOCHROME OXIDASE AND PROTEIN} ASSAYS

The manifold shown in Fig. 5 was used for both these assays. The protein assay was based on the Lowry et al. (1951) method. Bovine serum albumin solutions were used as standards. A few drops of chloroform were added to the sodium tartrate, carbonate, and protein standard solutions to prevent microbial contamination. Substrates and buffer solutions for all automated assays were prepared in sterile distilled water without further sterilisation. They were kept at $4^{\circ} \mathrm{C}$ for up to six weeks. In repeated sterility checks, no contaminants were found in these solutions. Nitrophenol and cytochrome oxidase substrates were freshly prepared each day to avoid chemical deterioration. Other reagents were pre-

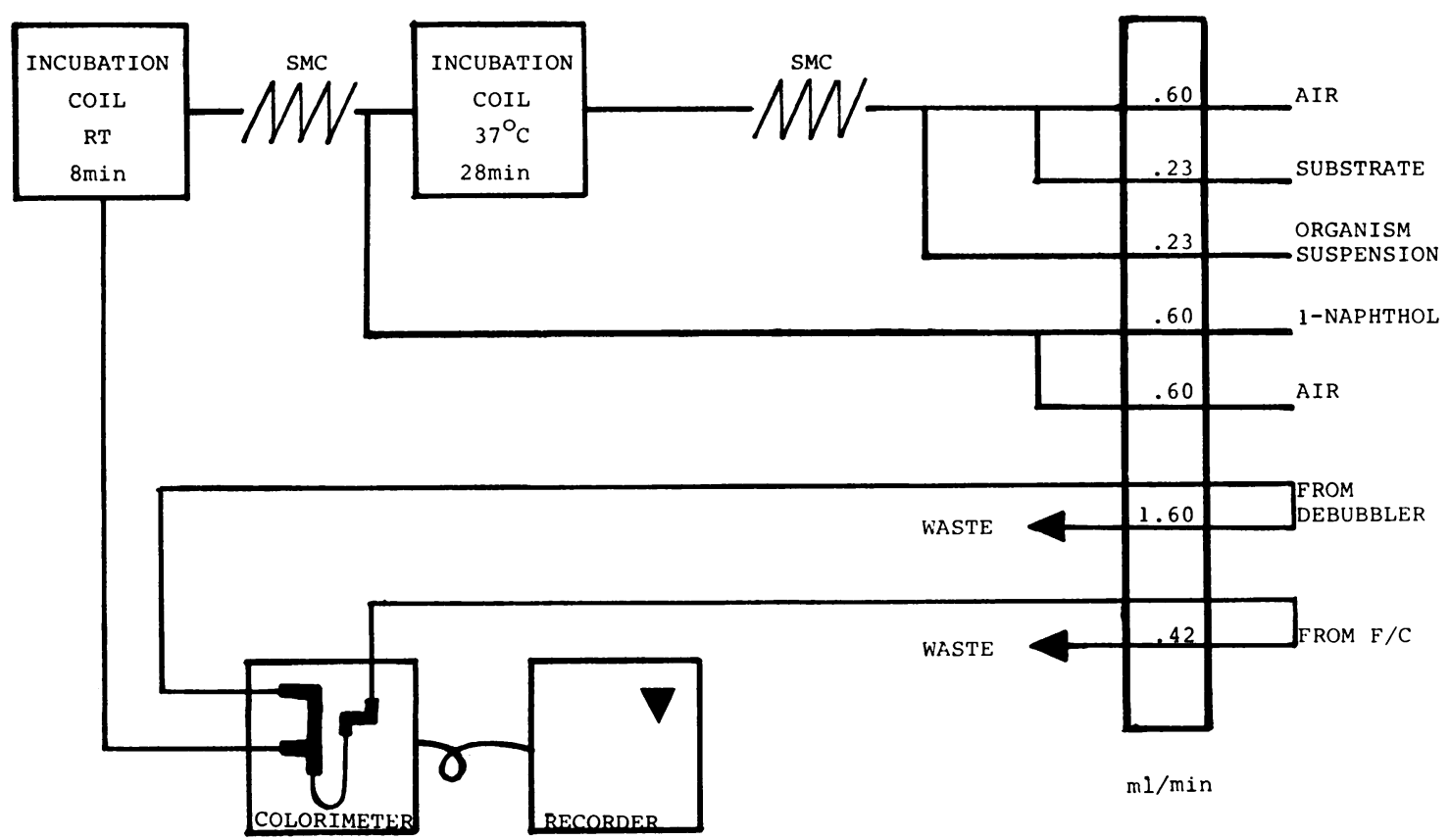

Fig.3 Manifold for assay of diacetyl producing system (V-P). Substrate solution contained $0 \cdot 3$ mol/l sodium pyruvate, $0.1 \mathrm{~mol} / \mathrm{l}$ acetate buffer, $\mathrm{pH} 4 \cdot 5,0.1 \mathrm{mmol} / \mathrm{l}$ thiamine pyrophosphate, and creatine $2 \mathrm{~g} / \mathrm{l}$. $1-\mathrm{Naphthol} 25 \mathrm{~g} / \mathrm{l}$ was dissolved in 2 mol/l sodium hydroxide. A $10 \mathrm{~mm}$ flow-cell, absorbance measured at $525 \mathrm{~nm}$. Total assay time $43 \mathrm{minutes}$. 


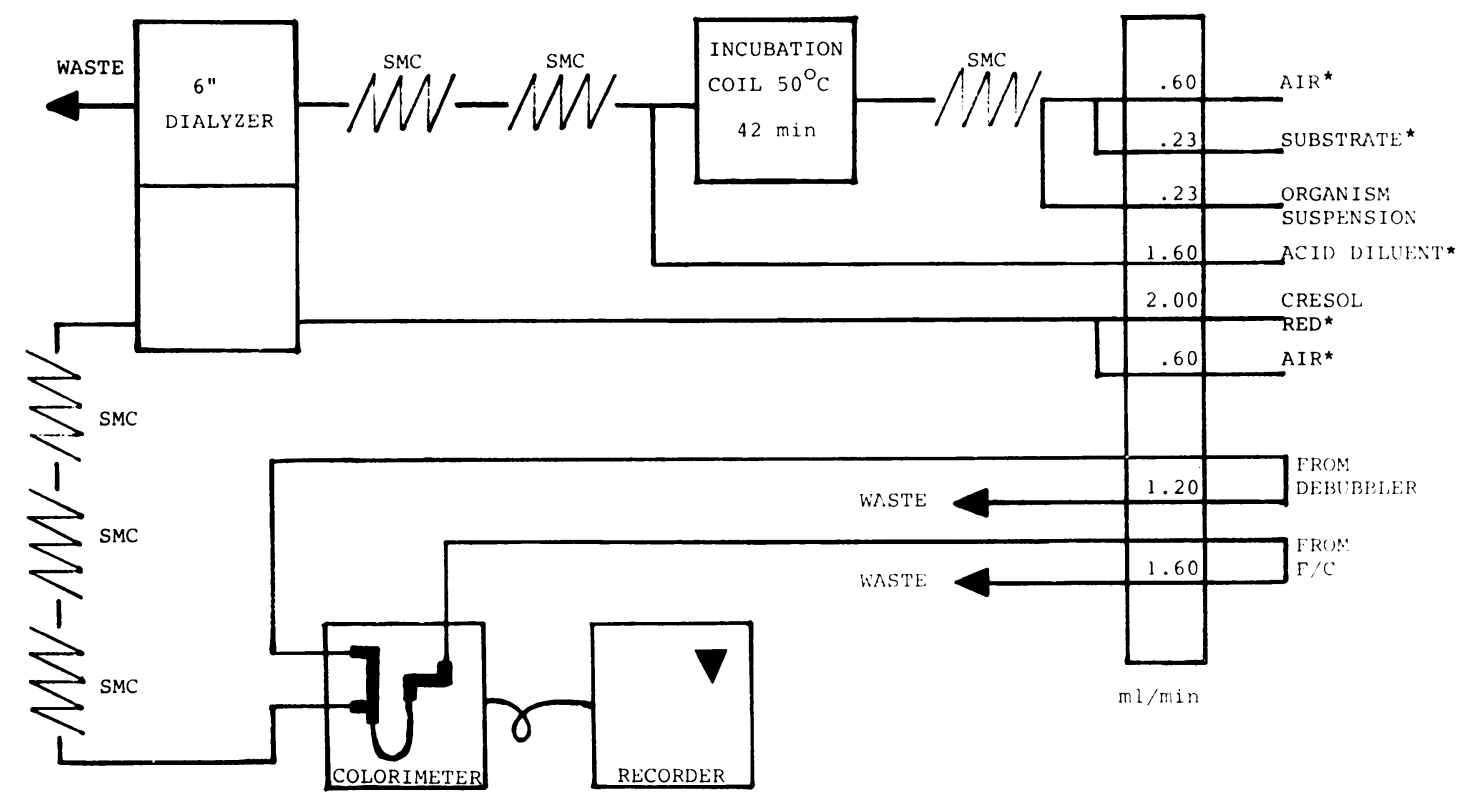

Fig. 4 Manifold for assay of glutamate decarboxylase. ${ }^{*} \mathrm{CO}_{2}$ absorbanis. Substrate solution contained $0 \cdot 1$ mol/l acetate buffer, pH 3.8, 0.05 mol/l sodium glutamate and pyridoxal phosphate $20 \mathrm{mg} / \mathrm{l}$. The $0.5 \mathrm{~mol} / \mathrm{l}$ sulphuric acid diluent contained Brij-35 (30\% Technicon) $1 \mathrm{ml} / \mathrm{l}$. The colour reagent contained $0.36 \mathrm{mmol} / \mathrm{l}$ Tris, $0.04 \mathrm{mmol} / \mathrm{l}$ ammonium hydroxide, Brij-35 $20 \mu \mathrm{l} / \mathrm{l}$, and cresol red $20 \mu \mathrm{g} / \mathrm{l}$. A $10 \mathrm{~mm}$ flow-cell, absorbance measured at $420 \mathrm{~nm}$. Total assay time 58 minutes.

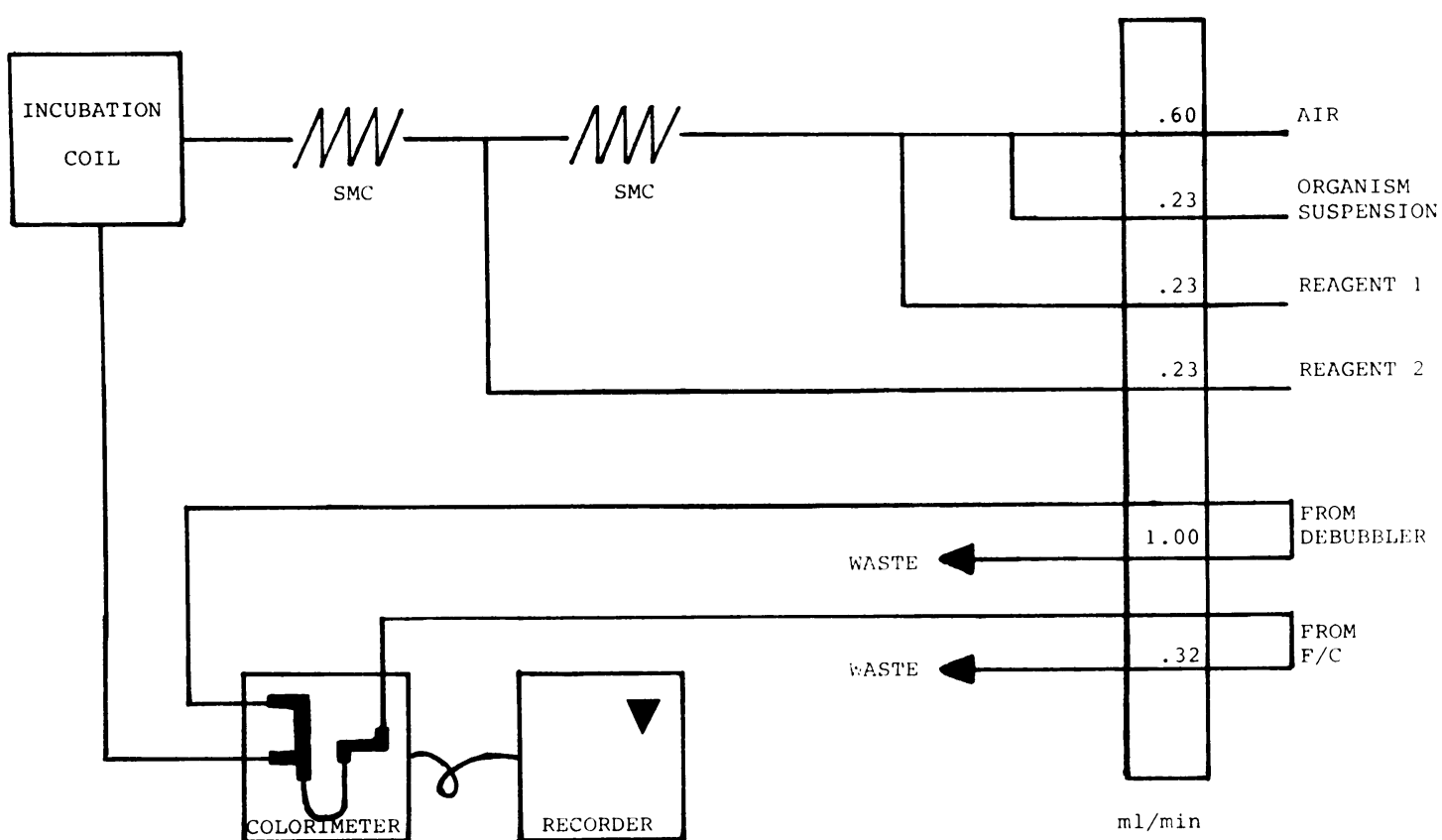

Fig. 5 Manifold for assay of cytochrome oxidase and protein. Cytochrome oxidase assay: reagent 1,0.05 mol/l Tris maleate buffer, pH 6.0; reagent $2,0.5 \mathrm{mmol} / \mathrm{l} N N^{\prime} N^{\prime}$-tetramethyl-p-phenylenediamine dihydrochloride and ascorbic acid $10 \mathrm{mg} / \mathrm{l}$. Incubation for 17 minutes at room temperature. A $10 \mathrm{~mm}$ flow-cell, absorbance measured at $550 \mathrm{~nm}$. Total assay time 22 minutes. Protein assay: reagent 1-alkaline copper solution prepared each day by mixing $2 \mathrm{ml}$ sodium potassium tartrate $(10 \mathrm{~g} / \mathrm{l})$ with $2 \mathrm{ml} \mathrm{CuSO} \mathrm{CH}_{4} .5 \mathrm{H}_{2} \mathrm{O}(5 \mathrm{~g} / \mathrm{l})$ and $46 \mathrm{ml} 0 \cdot 2 \mathrm{M} \mathrm{NaOH}$ containing $0 \cdot 37 \mathrm{M} \mathrm{Na} \mathrm{CO}_{3}$ in the order described, reagent 2- Folin and Ciocalteu's phenol reagent diluted 1:8 in distilled water each day. Bovine serum albumin solutions used as standards. A $10 \mathrm{~mm}$ flow-cell, absorbance measured at $660 \mathrm{~nm}$. Total assay time 22 minutes. 
pared in distilled water and kept at room temperature. Preparation of all reagents used in the automated assay occupied less than 1 hour per day.

\section{GENERAL FLOW CHART}

The methods were applied in a system (Fig. 6) that consisted of three channels running simultaneously: one channel assaying nitrophenol-releasing enzymes, the second ammonia-releasing enzymes and protein content, and the third channel diacetyl (V-P), cytochrome oxidase, and $\mathrm{CO}_{2}$ (glutamate decarboxylase). The stream from the sampler probe was divided into three, providing bacterial suspension to each of the channels. The manifolds for all assays were included in the combined manifold, though some had distilled water running through part of the time. The bacterial suspensions were placed on the sampler revolving plate, while substrates and buffers were provided in continuous streams. All bacterial suspensions were first tested for the activity of three enzymes (one enzyme in each of the channels). When the cycle was complete, the substrate buffer and sample lines were transferred manually to reagents for the next batch of three tests and the bacterial suspensions cycle was restarted. This process was repeated four times and included control runs with distilled water in the substrate lines to obtain the absorbance values of bacterial suspensions in the acid phosphatase, cytochrome oxidase, leucine ammonialyase, and urease assays.

The assays were performed at the rate of 20 samples an hour, with a $1: 3$ sample:wash ratio. Sterile physiological saline was used as the wash solution and to flush all lines for 30 minutes at the beginning and end of each working day. Under these conditions carry-over, as indicated by failure of return of absorbance to the original baseline, was relatively small (see, for example, Fig. 7). Moreover, carry-over of samples containing bacteria was of the same magnitude as that of the standard solutions of nitrophenol, ammonia, etc, suggesting that a build-up of bacteria did not occur in the autoanalyser tubes.

Results for the activity of three enzymes were available for each sample within 25-60 minutes of testing, depending on the nature of the assay. Results for all samples were available within 1-2 hours of the beginning of testing, depending on the number of samples tested. Characterisation and identification of each bacterial suspension was possible only after completion of all the tests. Results for all the tests and for all bacterial suspensions were available at the end of a working day.

\section{READING OF TEST RESULTS AND}

IDENTIFICATION

Peak heights were determined using a mechanical peak-height reader. Performance of this task occupied less than half an hour per day. When peaks obtained in the presence of organisms and substrate were higher than those obtained in the presence of the organisms and buffer, a positive activity was recorded. Each bacterial suspension was identified

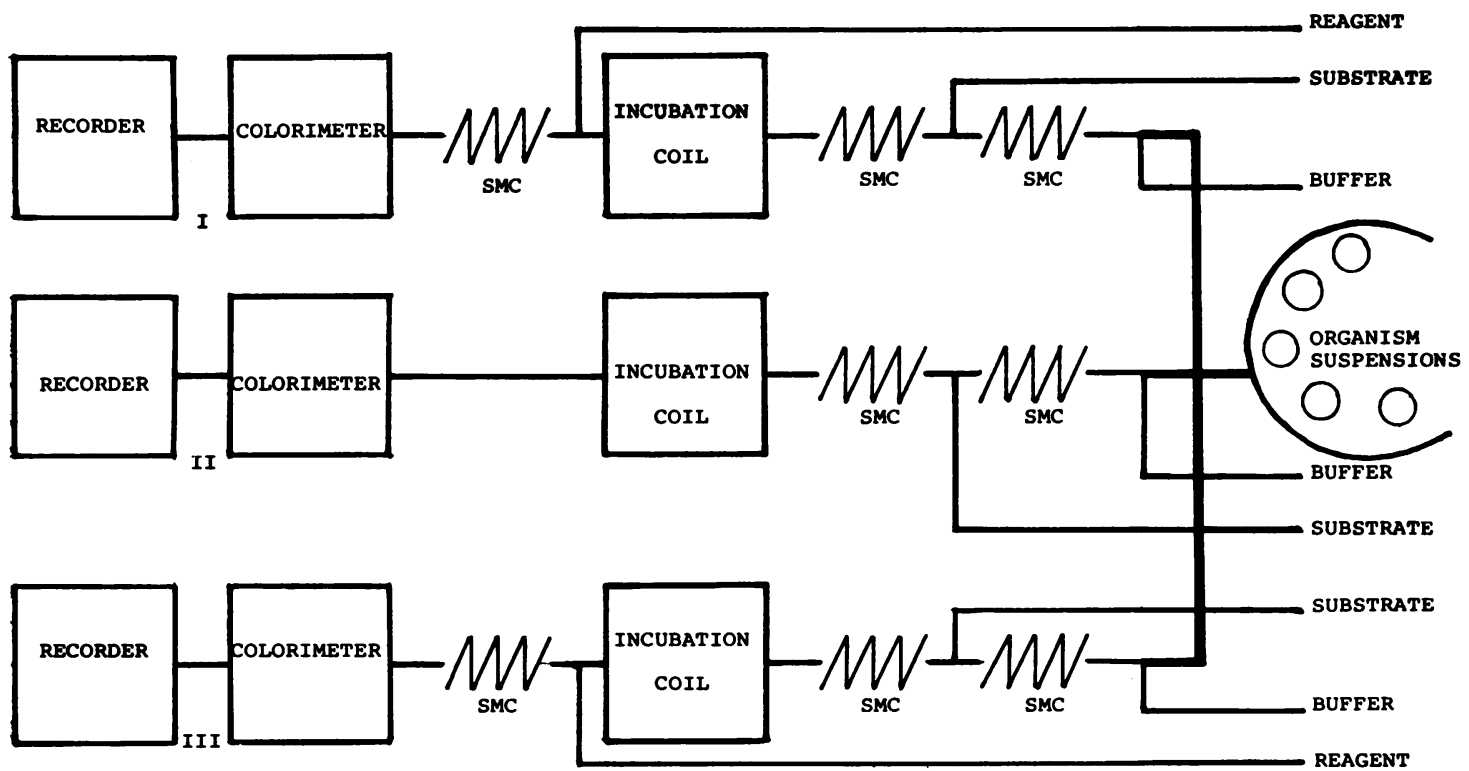

Fig. 6 Flow chart of a simultaneous 3-channel system. 

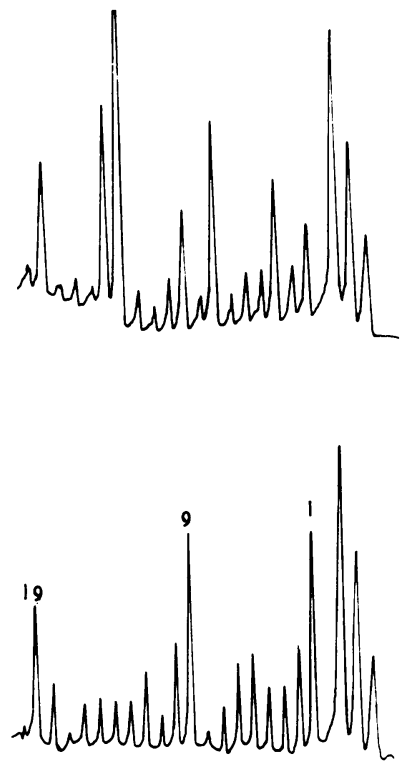

(a), (b)
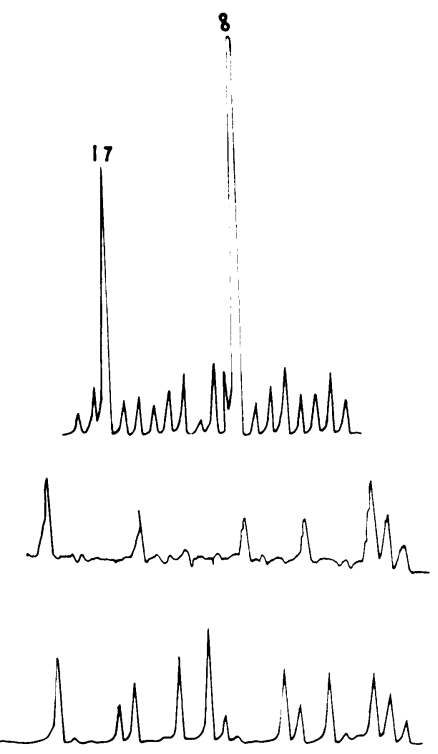

(c), (d), (e)
Fig. 7 Enzymatic activities of 19 strains tested on one day.

(a) acid phosphatase,

(b) p-nitrophenylalanine ammonia-lyase, (c) cytochrome oxidase, (d) diacetyl production, and (e) glutamate decarboxylase. Enzyme activities assayed by automated manifolds, as described in Methods. Numbered peaks indicate strains giving positive results. Order of samples: three appropriate standards (except in run (c) where standards were not included), (1) Proteus $s p$,

(2) E. coli, (3) Klebsiella $s p$,

(4) E. coli, (5) E. coli,

(6) E. coli, (7) Klebsiella

$s p,(8)$ Pseudomonas $s p$,

(9) Proteus $s p,(10)$. E. coli,

(11) Streptococcus $s p,(12)$

E. coli, (13) Klebsiella $s p$,

(14) Klebsiella $s p,(15) \mathrm{E}$.

coli, (16) E. coli, (17)

Pseudomonas $s p,(18)$

Klebsiella edwardsii,

(19) Proteus rettgeri. by comparing its pattern of activity (specific enzyme profile, SEP) with patterns of reference strains tested previously.

\section{CONVENTIONAL TESTS}

These were performed and interpreted as described by Cowan (1974) and are listed in Table $2 \mathrm{a}$ with the particular method indicated. The Methyl Red, Voges-Proskauer, and malonate-phenylalanine deamination media were all supplied by Difco Laboratories. The sulfide, indole, motility (SIM) medium was prepared from Difco dehydrated medium. All the remaining media were obtained from Southern Group Laboratories.

\section{COMPARISON OF IDENTIFICATION METHODS} Identification results of conventional and automated methods were compared after each week of testing. Samples that were identified as the same by both methods were classed as showing agreement. Those identified differently were tested again by both methods. The results of repeated testing are included in the total for each set.

\section{Results}

Examples of results obtained with the automated system are given in Fig. 7 showing (a) acid phosphatase, $(b) p$-nitrophenylalanine ammonia-lyase, $(c)$ cytochrome oxidase, $(d)$ diacetyl production, and $(e)$ glutamate decarboxylase activities of 19 strains tested on one day. Thus only strains of Pseudomonas sp (numbers 8 and 17) showed activity in the cytochrome oxidase test $(c)$, while only those of Proteus sp $(1,9$, and 19) gave positive results in the $p$-nitrophenylalanine ammonia-lyase test (b).

SET 1

A total of 198 bacterial suspensions were tested in this series. The suspensions made of 10 colonies in 5 $\mathrm{ml}$ saline were tested with the three-channel system. The list of conventional and automated tests and the pattern of results are given in Tables $2 a$ and $b$. The agreement achieved between identification based on automated and conventional methods was $99 \%$ (Table 3). The two strains that were not identified included a strain of Klebsiella sp showing only acid phosphatase activity, and a strain of Escherichia coli showing only $\beta$-galactosidase activity. Both were originally classed as unidentified by the automated system, but repeat tests agreed with identification by the manual method. With the right tests, therefore, good agreement between identification by conventional and automated methods can be achieved. 
Table 2 (a) Distribution of positive results (\%) in conventional tests of set 1

\begin{tabular}{|c|c|c|c|c|c|}
\hline & Method* & E. coli & Klebsiella $s p$ & Proteus $s p$ & Pseudomonas $s p$ \\
\hline Number of strains & & 125 & 39 & 16 & 18 \\
\hline Growth on citrate & 2 & $\mathbf{0}$ & 100 & 75 & 100 \\
\hline Motility & D† & 72 & $\mathbf{0}$ & 100 & 100 \\
\hline Deamination of phenylalanine & 1 & $\mathbf{0}$ & $\mathbf{0}$ & 100 & 0 \\
\hline \multicolumn{6}{|l|}{ Production of: } \\
\hline $\mathrm{H}_{2} \mathrm{~S}$ & $\mathbf{D}$ & $\mathbf{0}$ & 0 & 100 & 0 \\
\hline Indole & 2 & 100 & 10 & 12 & $\mathbf{0}$ \\
\hline Voges-Proskauer & 2 & 0 & 100 & 0 & $\mathbf{0}$ \\
\hline Utilisation of malonate & 1 & $\mathbf{0}$ & 100 & 0 & $\mathbf{0}$ \\
\hline \multicolumn{6}{|l|}{ Acid from: } \\
\hline Glucose & 1 & 100 & 100 & 100 & 0 \\
\hline Inositol & D & 0 & 100 & 0 & 0 \\
\hline Oxidase & 1 & 0 & o & 0 & 100 \\
\hline Urease & 2 & 0 & 100 & 100 & 0 \\
\hline
\end{tabular}

* Method as described by Cowan (1974).

† Donovan's medium for motility, $\mathrm{H}_{2} \mathrm{~S}$, and inositol fermentation (Southern Group Laboratory).

Table 2 (b) Distribution of positive results (\%) in automated tests of set 1

\begin{tabular}{|c|c|c|c|c|}
\hline & E. coli & Klebsiella $s p$ & Proteus $s p$ & Pseudomonas $s p$ \\
\hline $\begin{array}{l}\text { Number of strains } \\
\text { Acid phosphatase } \\
\text { Diacetyl production (V-P) } \\
\text { B-galactosidase } \\
\text { Glutamate decarboxylase } \\
\text { Leucine ammonia-lydse } \\
\text { Oxidase } \\
\text { p-Nitro phenylalanine ammonia-lyase } \\
\text { Urease }\end{array}$ & $\begin{array}{r}125 \\
1 \\
0 \\
94 \\
99 \\
0 \\
0 \\
2 \\
0\end{array}$ & $\begin{array}{r}39 \\
95 \\
51 \\
82 \\
0 \\
8 \\
0 \\
0 \\
62\end{array}$ & $\begin{array}{r}16 \\
100 \\
0 \\
0 \\
62 \\
94 \\
0 \\
100 \\
75\end{array}$ & $\begin{array}{r}18 \\
0 \\
0 \\
0 \\
0 \\
0 \\
100 \\
0 \\
10\end{array}$ \\
\hline
\end{tabular}

Table 3 Agreement between identification by conventional and automated methods

\begin{tabular}{lccccc}
\hline Set & E. coli & Klebsiella $s p$ & Proteus $s p$ & Pseudomonas $s p$ & Total \\
\hline No. strains tested & 125 & 39 & 16 & 18 & 193 \\
1 & 61 & 22 & & 5 & 96 \\
2 & 99 & 97 & 100 & & \\
Agreement between identification by the & & 100 & 100 & 99 \\
two methods & 99 & 100 & 100 & 100 \\
2 & & & & \\
\hline
\end{tabular}

\section{SET 2}

For the previous set of identifications it was found necessary to suspend 10 bacterial colonies in $5 \mathrm{ml}$ saline to provide enough material for test and control runs. For the next set control runs were dispensed with; instead, peak heights in the protein assay were used as guides for the absorbance of bacterial suspensions in the absence of substrates. This reduced the total volume needed for the nine assays to $0.99 \mathrm{ml}$. A total of 96 suspensions, each of a single colony in $1 \mathrm{ml}$ saline, was tested in this series. The automated tests were the same as in set 1 but without control runs; there was no change in the conventional tests. The level of agreement (Table 3) with this system was as good as that of set 1 . Thus it is now possible to identify certain bacterial taxa from organisms present in a single colony by the use of nine automated tests.

\section{Discussion}

CONVENTIONAL TESTS

The results for the conventional tests were as expected except for the urease test in which the number of strains of Pseudomonas sp giving a positive result was very small (Table $2 a)$. This was due to the use of a medium with a formula derived from that of Stuart et al. (1945). In this highly 
buffered medium strains of Pseudomonas do not produce an alkaline reaction (Cowan, 1974, p. 93).

\section{AUTOMATED TESTS}

For 25 strains tested per day by the automated system, the time involved in reagent preparation, inoculation, reading of test results, and discharge of contaminated material was less than 2 hours per day for one technician and compared favourably with time, labour, and cost of manual methods.

The results of the automated testing were easy to interpret. In most cases the enzymatic activities were considerable, and differentiation between positive and negative strains was clear (eg, Fig. 7c, d, and e). In some cases it was necessary to measure peak heights of control and activity charts for determination of activity. In comparison with conventional tests (Table $2 \mathrm{a}$ and $\mathrm{b}$ ), results of automated tests were slightly less homogeneous (ie, the percentage of strains giving positive results was different from 0 or 100).

\section{CHOICE OF AUTOMATED TECHNIQUE}

It is necessary to consider whether continuous-flow techniques are the most suitable for enzyme assays of bacterial suspensions for the purpose of diagnostic bacteriology. The advantage of continuous-flow methods lies in the flexibility of the system permitting addition of a number of reagents, ability to separate various fractions of the reaction mixture (eg, use of hydrophobic membrane for detection of $\mathrm{CO}_{2}$ produced by glutamate decarboxylase), and ability to complete the assay with a relatively small total volume of assay mixture. This last feature enabled the detection of activity of enzymes in bacteria present in one-tenth of a colony ( $c$ 2-7 $\mu \mathrm{g}$ of protein). The disadvantage of the continuous-flow system for such small amounts of enzyme is the slow throughput of samples. Rates higher than 25 samples per hour were not possible because of carry-over problems. Nevertheless the continuous-flow techniques used provided valuable information about enzymatic activities of bacteria freshly isolated from clinical specimens and were very useful for selection of the tests most suitable for characterisation of clinically important bacteria. A 9-channel system would permit identification of a strain in 1 hour at the rate of 25 strains per hour.

COMPARISON OF IDENTIFICATION BY AUTOMATED AND MANUAL METHODS

Agreement between identification by automated and conventional methods was very high $(99$ or $100 \%$, Table 3). However, at present such agreement has been shown only within a limited number of bacterial taxa. The small number of species included in these studies is a reflection of the frequency of occurrence of the various pathogens in urinary tract infections. The guideline for choice of colonies for identification was: 'any MacConkey agar primary isolation plate showing growth of a single type of Gram-negative organism, with preference towards non-lactose fermenting organisms'. Even so $E$. coli strains constituted $60 \%$ of the population. Previous experience has shown that the behaviour of culture collection strains was slightly different from that of freshly isolated ones as regards frequency of positive response to some tests. Further tests are now in progress to establish the ability of the system to identify other Gram-negative species likely to occur in urinary tract infections. Attempts to identify Gram-positive bacteria cultured from urine specimens by the automated method showed that they could be differentiated from Gram-negative bacteria, but more tests are necessary for differentiation within this group.

The use of enzyme profiles as a means of characterisation and identification of bacteria can be justified on both theoretical and practical grounds (Kersters and De Ley, 1967; Bascomb, 1980). As enzymes are responsible for most biochemical changes within the bacterial cells and in the bacterial environment, the enzyme assays could theoretically replace any conventional test used for bacterial characterisation. From the practical point of view, the short incubation periods needed for enzyme assays permit the use of non-sterile reagents, so saving in labour and cost of testing. The volumes of test media used in our system were 10 - to 50 -fold smaller than in conventional testing.

The most important advantage of the automated system is the saving in testing time. In a typical clinical diagnostic laboratory urine specimens are plated on MacConkey agar. Those in which microscopy shows large numbers of white cells are also tested directly for antibiotic sensitivity. Thus on the following day a report can usually be sent to the clinician giving provisional identification of the organism and its antibiotic sensitivity pattern. Identification is confirmed by conventional testing, the results of which may be available only after an additional 24-48 hours. The automated system can provide definite identification one day earlier even on a single colony.

The decrease in incubation times needed for the automated assay was achieved by testing for individual enzymes under optimal conditions, increasing the concentration of the bacterial inoculum in the final incubation mixture, using synthetic substrates which yield products with high extinction coefficients, and, most important, using instrumentation for measuring the reaction products. 
However, the automated system, because of its short incubation periods, can only measure enzymes already present in the bacteria. Conventional methods frequently detect induced enzymes, which appear in the course of the test. This difference can lead to discrepancies in the results for individual enzymes between the two methods. For example, all strains of klebsiella and proteus tested gave positive conventional urease tests. In the automated urease assay, only $62 \%$ and $75 \%$, respectively, were positive (Table $2 a$ and $b$ ), suggesting that urease is an induced enzyme in these two species. It becomes necessary to characterise bacterial taxa by tests based solely on constitutive enzymes.

Studies to provide a new identification matrix, based on rapid automated tests that will include other bacteria commonly found in medical specimens, are now in progress.

We are grateful to Professor A A Glynn for his encouragement throughout the work and help in preparation of the manuscript. We thank Mrs $T$ Graff for technical assistance. The work was made possible by a grant from the Medical Research Council. Some extra equipment was provided by the North West Thames Regional Research Committee.

\section{References}

Bascomb, S. (1976). Rapid identification of bacteria from clinical specimens by continuous flow analysis. In Proceedings of the 2nd International Symposium on Rapid Methods and Automation in Microbiology, edited by H. H. Johnston and S. W. B. Newsom, p. 53. Learned Information (Europe), Oxford.

Bascomb, S. (1980). Identification of bacteria by measurement of enzyme activities and its relevance to the clinical diagnostic laboratory. In Microbiological Classification and Identification, edited by M. Goodfellow and R. G. Board. Academic Press, New York.

Bascomb, S., and Grantham, C. A. (1973). "Specific enzyme profile", an automated method for bacterial classification. In Abstracts of International Association of Microbiological Societies 1st International Congress for Bacteriology, Volume II, p. 132. Jerusalem.

Bascomb, S., and Grantham, C. A. (1975). Application of automated assay of asparaginase and other ammoniareleasing enzyme to the identification of bacteria. In Some Methods for Microbiological Assay (Society for Applied Bacteriology Technical Series No. 8), edited by R. G. Board and D. W. Lovelock, pp. 29-54. Academic Press, New York.

Bettelheim, K. A., Kissin, E. A., and Thomas, A. J. (1970). An automated technique for the determination of ammonia produced by bacteria. In Automation, Mechanization and Data Handling in Microbiology (Society for Applied Bacteriology Technical Series No. 4), edited by A. Baillie and R. J. Gilbert, pp. 133-136. Academic Press, New York.
Buissière, J., Fourcard, A., and Colobert, L. (1967). Usage de substrats synthétiques pour l'étude de l'équipement enzymatique de microorganismes. Comptes Rendus Hebdomadaires des Séances de l'Académie des Sciences; D, 264, 415-417.

Cowan, S. T. (1974). Cowan and Steel's Manual for the Identification of Medical Bacteria, 2nd edition. Cambridge University Press, Cambridge.

Dealy, J. D., and Umbreit, W. W. (1965). The application of automated procedures for studying enzyme synthesis in Escherichia coli. Annals of the New York Academy of Sciences, 130, 745-750.

Gerke, J. R., and Ferrari, A. (1968). Review of chemical and microbiological assay of antibiotics. In Automation in Analytical Chemistry (Technicon Symposium, 1967), Volume 1, pp. 531-541. Mediad, White Plains, New York.

Humble, M. W., King, A., and Phillips, I. (1977). API ZYM: a simple rapid system for the detection of bacterial enzymes. Journal of Clinical Pathology, 30, 275-277.

Johnston, H. H., Mitchell, C. J., and Curtis, G. D. W. (1976). Automation in clinical microbiology. A system for urine specimens. In Proceedings of the 2nd International Symposium on Rapid Methods and Automation in Microbiology, edited by H. H. Johnston and S. W. B. Newsom, pp. 210-213. Learned Information (Europe), Oxford.

Kamoun, P. P., Pleau, J. M., and Man, N. K. (1972). Semiautomated method for measurement of guanidinosuccinic acid in serum. Clinical Chemistry, 18, 355-357.

Kersters, K., and De Ley, J. (1967). Enzymic tests with resting cells and cell-free extracts. In Methods in Microbiology, Volume 6A, edited by J. R. Norris and D. W. Ribbons, pp. 33-52. Academic Press, New York.

Kilian, M., and Bülow, P. (1976). Rapid diagnosis of Enterobacteriaceae. I. Detection of bacterial glycosidases. Acta Pathologica Microbiologica Scandinavica, 84B, 245-251.

Leclerc, H. (1967). Mise en évidence de la décarboxylase de l'acide glutamique chez les bactéries à l'aide d'une technique automatique. Annales de l'Institute Pasteur, 112, 713-731.

Lowry, O. H., Rosebrough, N. J., Farr, A. L., and Randall, R. J. (1951). Protein measurement with the Folin-phenol reagent. Journal of Biological Chemistry, 193, 265-275.

Moran, J. W., and Witter, L. D. (1976). An automated rapid test for Escherichia coli in milk. Journal of Food Science, 41, 165-167.

Picciolo, G. L., Thomas, R. R., Chappelle, E. W., Taylor, R. E., Jeffers, E. J., and McGarry, M. A. (1976). Automated determination of microbial levels for waste water effluent using luminescent assays. In Proceedings of the 2nd International Symposium on Rapid Methods and Automation in Microbiology, edited by H. H. Johnston and S. W. B. Newsom, p. 152. Learned Information (Europe), Oxford.

Stuart, C. A., van Stratum, E., and Rustigian, R. (1945). Further studies on urease production by Proteus and 
related organisms. Journal of Bacteriology, 49, 437-444.

Tappel, A. L., and Beck, C. (1968). Automated multiple enzyme monitor for column chromatography. In Automation in Analytical Chemistry (Technicon Symposium, 1967), Volume 1, pp. 593-598. Mediad, White Plains, New York.

Trinel, P. A., and Leclerc, H. (1972). Automation de l'analyse bactériologique de l'eau. 1. Etude d'un nouveau test spécifique de contamination fécale et de conditions optimales de sa mise en évidence. Water
Research, 6, 1445-1458.

Wade, H. E., Robinson, H. K., and Phillips, B. W. (1971). Asparaginase and glutaminase activities of bacteria. Journal of General Microbiology, 69, 299-312.

Requests for reprints to: Dr S Bascomb, St Mary's Hospital Medical School, University of London, Department of Bacteriology, Wright-Fleming Institute, London W2 1PG, UK. 